$$
\begin{gathered}
\text { RECTIFICATIF } \\
\text { au Bulletin Géodésique } n^{\circ} 87 \\
\text { du } 1^{\text {er Mars } 1968}
\end{gathered}
$$

Page 53

Au lieu de :

$$
\text { 1.1. MUELLER }
$$

Department of Geodetic Science

The Ohio State University

\title{
GLOBAL SATELLITE TRIANGULATION AND TRILATERATION
}

\author{
Lire: \\ I.I. MUELLER, \\ F.D. HOTTER, E.J. KRAKIWSKY and A.J. POPE \\ Department of Geodetic Science \\ The Ohio State University
}

GLOBAL SATELLITE TRIANGULATION AND TRILATERATION 